\title{
Improved Enzyme Catalytic Characteristics upon Glutaraldehyde Cross-Linking of Alginate Entrapped Xylanase Isolated from Aspergillus flavus MTCC 9390
}

\author{
Bharat Bhushan, ${ }^{1,2}$ Ajay Pal, ${ }^{1}$ and Veena Jain ${ }^{1}$ \\ ${ }^{1}$ Department of Chemistry \& Biochemistry, CCS Haryana Agricultural University, Hisar 125004, India \\ ${ }^{2}$ HCP Division, ICAR-CIPHET (Central Institute of Post-Harvest Engineering and Technology), Ludhiana, Abohar 152116, India
}

Correspondence should be addressed to Bharat Bhushan; buddingbiochemist@gmail.com

Received 13 July 2015; Revised 6 August 2015; Accepted 6 August 2015

Academic Editor: Raffaele Porta

Copyright (C) 2015 Bharat Bhushan et al. This is an open access article distributed under the Creative Commons Attribution License, which permits unrestricted use, distribution, and reproduction in any medium, provided the original work is properly cited.

Purified fungal xylanase was entrapped in alginate beads. Its further cross-linking using glutaraldehyde resulted in large enzyme aggregates which may function as both a catalyst and a support material for numerous substrate molecules. Enzyme cross-linking presented a negative impact on enzyme leaching during repeated washings and recovery of enzyme activity was substantial after twelve cycles of usage. The entrapment followed by cross-linking doubled the total bound activity and also greatly improved the enzyme stability at extreme chemical environment. The wide $\mathrm{pH}$ stability, better thermo- and storage stability, lowered $K_{m}$ value, and protection from some metal ions are salient achievements of present immobilization. The study shows the efficacy, durability, and sustainability of immobilized catalytic system which could be efficiently used for various juice processing operations.

\section{Introduction}

Cloudy fruit juice is a colloidal suspension in which the continuous medium is a solution of pectin, xylan, sugars, and malic acid while the dispersed matter is mainly formed of cellular tissue comminuted during fruit processing [1]. To obtain a clear juice, these suspended particles need to be removed in a process known as clarification. This procedure helps to remove active haze precursors yielding a more clear juice and also decreases the potential for haze formation during storage [2]. Enzymatic hydrolysis using xylanase and associated enzymes plays a very important role in the removal of undesirable turbidity [3].

In view of the variety of their industrial applications and wide range of stabilities under different reaction conditions, xylanases are under extensive study. There has been increasing focus on thermostable acidophilic xylanases in combination with other cell wall degrading enzymes for use in juice clarification and yield improvement $[2,4]$. Xylanases improve juice yield by means of liquefaction and hydrolysis of those substances which hinder in juice clarification $[2$, 5]. However, these enzymes exhibit certain problems such as poor stability, high production costs, and difficulty in recovery. These hurdles should be overcome for worldwide industrial adoption of the enzymes for economic viable process and its commercial realization. Therefore, it is necessary to select the microbial isolate with a potential of higher enzyme production with desirable attributes.

The utilization of free enzymes always presents problems such as low stability, low product recovery, and less repeated use. So the cost-effective immobilization of enzymes for maximum reusability and broader industrial applicability is required. The techniques of macromolecule immobilization have revolutionized the prospects of enzyme applications in industry. Although the best method of immobilization differs from enzyme to enzyme, from application to application, from carrier to carrier, and from peculiarities of specific applications to others, yet the criteria for assessing the robustness of immobilized enzymes remain the same $[6,7]$.

To date numerous methods of enzyme immobilization are available but the effectiveness of each one depends upon reaction conditions, process of product formation, and its cost evaluation. Different methods, namely, covalent 
binding, adsorption, adhesion, aggregation, and entrapment, using diverse support like alginate, chitosan, polyacrylamide, agarose, cellulose, dextrans, polymers of polyvinyl alcohol (PVA), and bentonite have been used in the recent past to immobilize either the whole cells or the enzymes. Scientists are actively engaged in manipulating various immobilization methods for various enzymatic transformations and it has been observed that entrapment is the easiest process to scale up because it offers diverse optimization strategies with different procedures and conditions [8].

Entrapment within insoluble calcium alginate beads has been shown to be the most effective approach due to their biocompatibility (nontoxic), low cost, effective particle size, and availability [9-14]. Alginic acid is a polyuronic acid extracted from marine algae and forms gel in the presence of cations such as calcium, zinc, iron, aluminum, and copper [8].

Since xylanase also plays a crucial role in many food processing industries, it was thought worthwhile to immobilize the enzyme on alginate to increase its operational utility on commercial scale. The pores formed with $2 \%$ alginate had diameter in the range of 5-200 $\mathrm{nm}$ through which small sized enzyme molecules $(4-8 \mathrm{~nm})$ can easily leak out. So we tried to cross-link the entrapped enzymes to produce stable enzyme complexes with reduced diffusion characteristics. The present investigation shows the effect of cross-linking modification on the physicokinetic properties of alginateentrapped enzyme.

\section{Materials and Methods}

2.1. Microorganism and Chemicals. Aspergillus flavus MTCC 9390 isolated from decaying organic matter in the soil was used in this study. Ammonium sulfate, Sephadex G-100, and oat spelt xylan were products of Sisco Research Laboratory Chemicals (Mumbai, India). Glutaraldehyde solution and sodium alginate were supplied by Fluka (Buch, Switzerland). All other chemicals used were of analytical grade.

2.2. Cultivation and Production. The fungal strain (A. flavus MTCC 9390) was incubated at $45^{\circ} \mathrm{C}$ for $144 \mathrm{~h}$ in submerged fermentation in preoptimized production medium $(\mathrm{pH} 6.0)$ with the following composition $\left(\mathrm{gL}^{-1}\right): \mathrm{KH}_{2} \mathrm{PO}_{4}, 1.0 ; \mathrm{NaNO}_{3}$, 2; $\mathrm{KCl}, 0.5$; yeast extract, 0.5 ; peptone, $0.5 ; \mathrm{MgSO}_{4} \cdot 7 \mathrm{H}_{2} \mathrm{O}$, $0.5 ; \mathrm{FeSO}_{4}, 0.01 ; \mathrm{ZnSO}_{4}, 0.001 ; \mathrm{CuSO}_{4}, 0.0005$; and oat-spelt xylan, 1.0 as the carbon source [15]. The resulting mycelial mass was separated from broth by filtration through muslin cloth followed by centrifugation at $10000 \times \mathrm{g}$ for $10 \mathrm{~min}$ at low temperature to obtain cell-free culture filtrate. The extracellular proteins in supernatant (crude enzyme extract) were precipitated using $70 \%$ saturation of ammonium sulphate at $4^{\circ} \mathrm{C}$ and the obtained precipitates were redissolved in acetate buffer $(50 \mathrm{mM}, \mathrm{pH} 6.0)$. Xylanase was purified to thirteen folds through molecular exclusion chromatography using Sephadex G-100 [2] and used for immobilization studies.

2.3. Optimization of Immobilization. The purified xylanase was immobilized by entrapment within alginate beads. The effects of different concentrations of constituents for building the support material were investigated by varying them to obtain stable alginate-xylanase beads (alginate from 1.0 to $5.0 \%$ and $\mathrm{CaCl}_{2}$ from 0.05 to $0.3 \mathrm{M}$ ). Initially, beads of different sizes were obtained by using needles of variable gauges (G). The beads were collected using filter funnel and stored overnight in $0.02 \mathrm{M} \mathrm{CaCl}_{2}$ solution at $4^{\circ} \mathrm{C}$ for hardening. During entrapment, the ratio of alginate-enzyme solution to calcium chloride was kept 1:2(v/v). The calcium chloride suspension was centrifuged at $3000 \times \mathrm{g}$ for $10 \mathrm{~min}$ to estimate unbound enzyme. One gram of beads was treated with $10 \mathrm{~mL}$ of glutaraldehyde $(1 \%)$ prepared in 100 mM MES (2-(N-morpholino)ethanesulfonic acid) buffer ( $\mathrm{pH}$ 6.0) under continuous magnetic stirring for $90 \mathrm{~min}$ at room temperature. At this step, the ratio between beads and glutaraldehyde was opted 1:10 as described by us earlier [5]. The treated beads were washed with buffers of $25 \mathrm{mM}$ acetate buffer ( $\mathrm{pH}$ 5.5) to remove excess glutaraldehyde.

2.4. Enzyme Preparations. The purified xylanase was used as free enzyme preparation [2]. The beads prepared without glutaraldehyde treatment were referred to as entrapped enzymes [2] and glutaraldehyde treated beads were referred to as polymer support with cross-linked enzymes.

2.5. Enzyme Assay. Twenty-five small beads were suspended in $5 \mathrm{~mL}$ of $50 \mathrm{mM}$ acetate buffer ( $\mathrm{pH} \mathrm{6.0)}$ to calculate the xylanase activity [16]. For the estimation of free and washed out xylanase, one $\mathrm{mL}$ of $1 \%$ oat spelt xylan solution (in $0.05 \mathrm{M}, \mathrm{pH} 6.0$ acetate buffer) was mixed with $0.1 \mathrm{~mL}$ enzyme solution and incubated for $15 \mathrm{~min}$ at $60^{\circ} \mathrm{C}$. The reaction was stopped by adding $1 \mathrm{~mL}$ of $1 \% 3^{\prime}, 5^{\prime}$-dinitrosalicylic acid (DNS) reagent. The mixture was heated for $5 \mathrm{~min}$ at $100^{\circ} \mathrm{C}$ in a boiling water bath and cooled. Absorbance of sample was measured at $540 \mathrm{~nm}\left(A_{540}\right)$ against the substrate blank. A standard curve of xylose ranging from 0 to $1000 \mu \mathrm{g} \mathrm{mL}^{-1}$ was constructed and used to estimate the released xylose. One unit (U) of enzyme activity is defined as the amount of enzyme liberating $1 \mu \mathrm{mol}$ of xylose equivalents in $1 \mathrm{~min}$ under the assay conditions. Protein content was estimated by the method of Lowry et al. [17].

2.6. Biochemical and Kinetic Characterization. The effect of temperature and $\mathrm{pH}$ on free and bound xylanases (with and without cross-linking) was evaluated in the temperature range $30-90^{\circ} \mathrm{C}$ and $\mathrm{pH}$ range $4.0-7.5$. The results of optimal $\mathrm{pH}$ determination were obtained by assaying the enzyme preparations at constant substrate (1\%) and temperature $\left(60^{\circ} \mathrm{C}\right)$. The buffers of constant molarity $(100 \mathrm{mM})$ were acetate ( $\mathrm{pH}$ 2.0-5.5), MES ( $\mathrm{pH}$ 5.5-6.5), and glycine- $\mathrm{NaOH}$ ( $\mathrm{pH} 7.0-8.5)$. The $\mathrm{pH}$ stability of all enzyme preparations was evaluated by preincubating at different $\mathrm{pH}$ values for $60 \mathrm{~min}$ at $50^{\circ} \mathrm{C}$. Initial activity was considered $100 \%$ and the residual activity was measured. Temperature optima were determined by assaying different forms of xylanase at different temperatures. The optimum value of $\mathrm{pH}$ was used for different enzyme preparations (i.e., $100 \mathrm{mMMES}$ buffer ( $\mathrm{pH} 5.0$ for free, $\mathrm{pH} 5.5$ for entrapped, and $\mathrm{pH} 6.0$ for cross-linked enzyme)). Thermal stability was determined 


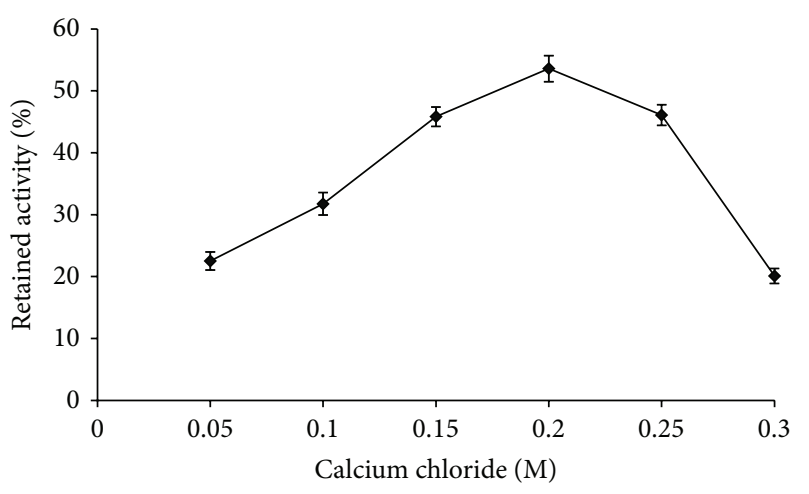

(a)

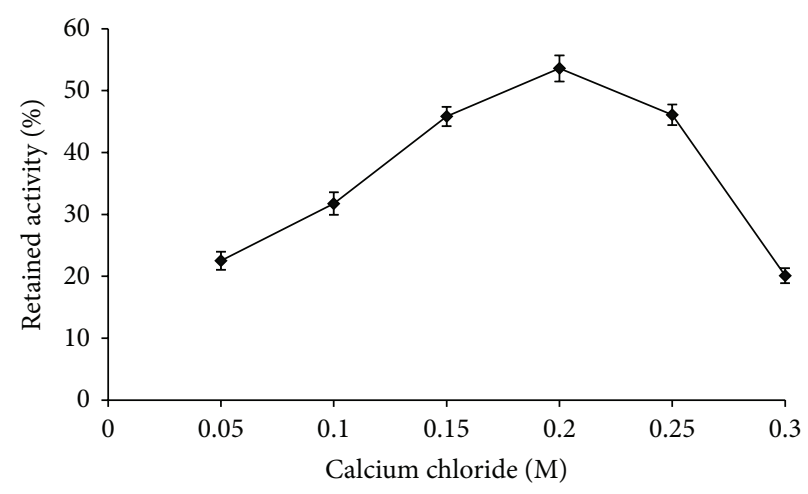

(b)

FIGURE 1: Effect of calcium chloride (a) and duration of cross-linking (b) on percent xylanase activity retention.

by incubating enzyme preparations at $70^{\circ} \mathrm{C}$ for $240 \mathrm{~min}$. Enzyme aliquots were withdrawn regularly and the residual activity was calculated. To determine the storage stability, the enzyme preparations were stored at 5 and $25^{\circ} \mathrm{C}$. The aliquots were withdrawn at regular intervals and residual activity was determined. The effect of metal ions $(5 \mathrm{mM})$ and chemical inhibitors $(1 \mathrm{mM})$ on xylanase activity was studied at their optimal $\mathrm{pH}$ and temperature. Enzyme activity without modifiers was considered $100 \%$. Kinetic constants over a wide range of substrate/xylan concentration (0.5-5.0\%) were determined at their optimum $\mathrm{pH}$ and temperature. The $K_{m}$ and $V_{\max }$ values were calculated from the kinetic data using the double reciprocal plot of Lineweaver and Burk [18]. Reaction progress was monitored by incubating xylan and xylanases for different time intervals (15-60 $\mathrm{min})$ at their optimal reaction conditions.

2.7. Desorption and Reusability. Desorption studies were conducted by dropwise pouring the different concentrations of buffered sodium dodecyl sulfate (SDS) on immobilized enzymes. The enzyme activity in bead and washing supernatant was estimated. Enzyme activity in entrapped polymer beads in first run was considered $100 \%$.

2.8. Statistical Analysis. The experiments were performed in triplicates and their mean values were taken into consideration for calculation.

\section{Results and Discussion}

3.1. Effect of Constituents on Enzyme Immobilization. Enzyme entrapment in beads depends on the concentration of sodium alginate and calcium ions. So the effect of concentration of these constituents was investigated on immobilization efficiency. Size of the beads also affects the immobilization efficiency. In the present study, xylanase entrapped beads were prepared by passing through a syringe of $18 \mathrm{G}$ needle. The smaller beads obtained with $18 \mathrm{G}$ needles showed highest immobilization efficiency due to increased surface area (data not shown). The immobilization process was further optimized with respect to the concentration of $\mathrm{CaCl}_{2}$ (Figure 1).
Afterwards, the beads were suspended in glutaraldehyde solution for enzyme cross-linking. The results (Table 1(a)) showed that immobilization efficiency and activity retention increased 16 and $46 \%$, respectively, whereas fold enrichment was enhanced 2-fold by cross-linking. The purpose of adding cross-linker was to cross-link the entrapped enzymes so as to make their aggregates and thereby reduce their leakage. On comparing the unbound and bound activity in the presence and the absence of glutaraldehyde, it was found that crosslinked preparation had minimum leakage (Table 1(a)).

Immobilization of $\beta$-glucosidase isolated from Aspergillus niger in hen egg white was studied by Karimpil et al. [19] who showed that the immobilized enzyme retained approximately 55\% activity. Roy et al. [20] reported that xylanolytic activity immobilized on Eudragit L-100 decreased with increase in volume of enzyme loaded on the beads and this was attributed to overcrowding of the enzyme on the surface.

3.2. pH Optima and Stability of Entrapped and Cross-Linked Enzyme. The $\mathrm{pH}$ optima of all the three enzyme preparations, namely, free, entrapped, and cross-linked xylanase, were found in the acidic range. But the $\mathrm{pH}$ optima of both the immobilized preparations were on higher side as compared to free enzyme (Figure 2(a)). A slight change in $\mathrm{pH}$ optima of cross-linked enzyme was observed which may be due to its surface and residual charge interaction with glutaraldehyde during cross-linking. The $\mathrm{pH}$ stability assays showed that preincubation of enzyme preparations in $\mathrm{pH}$ range 5.0-7.0 had no negative impact on enzyme activity measured at their optimum $\mathrm{pH}$ (Figure 2(b)). Results of the study show that all the three preparations have almost identical acidic $\mathrm{pH}$ stability. It was also observed that extreme acidic and alkaline $\mathrm{pH}$ were detrimental to protein structure and/or its ionic environment.

Optimum $\mathrm{pH}$ of immobilized inulinase was found slightly on lower side (4.0) as compared to its free form ( $\mathrm{pH}$ 4.5) [21]. Increased $\mathrm{pH}$ optima of peroxidase and amylase immobilized in calcium alginate gels and covalently immobilized xylanase have also been documented $[5,13,22]$. A shift in $\mathrm{pH}$ optima of pectinase immobilized in alginate using glutaraldehyde was also noticed by Li et al. [23]. 
TABLE 1: (a) Effect of cross-linking on the process parameters and activity of entrapped and cross-linked xylanase from A. flavus MTCC 9390. (b) Effect of metal ions and some chemicals on different forms of xylanase activity from A. flavus MTCC 9390.

(a)

\begin{tabular}{lcccccc}
\hline Preparations & $\begin{array}{c}\text { Theoretical } \\
\text { maximal bound } \\
\text { activity (U) }\end{array}$ & $\begin{array}{c}\text { Unbound activity } \\
(\mathrm{U})\end{array}$ & $\begin{array}{c}\text { Bound (actual) } \\
\text { activity (U) }\end{array}$ & $\begin{array}{c}\text { Immobilization } \\
\text { efficiency }^{*}\end{array}$ & $\begin{array}{c}\text { Activity }_{\text {retention }^{\#}} \\
\text { Fold enrichment }\end{array}$ \\
\hline Entrapped & $114.67 \pm 4.15$ & $98.55 \pm 3.06$ & $87.4 \pm 3.63$ & $76 \pm 2.24$ & $53 \pm 3.55$ & $41 \pm 3.00$ \\
Cross-linked & $210.14 \pm 6.31$ & $3.08 \pm 0.35$ & $194.75 \pm 6.53$ & $92 \pm 3.17$ & $99 \pm 3.78$ & $91 \pm 7.00$ \\
\hline
\end{tabular}

${ }^{*}$ Immobilization efficiency $=$ (actual bound activity/maximum theoretical bound activity) $\times 100$.

\#Activity retention $=($ maximum theoretical bound activity/total activity employed for immobilization $) \times 100$.

${ }^{\dagger}$ Fold enrichment $=$ (actual bound activity/total activity employed for immobilization $) \times 100$.

Note: immobilization effectiveness factor can be calculated from immobilization efficiency by dividing it with 100. Immobilization yield can be calculated from fold enrichment by dividing it with 100 .

Enzyme units used for the immobilization: $213.22 \mathrm{UmL}^{-1}$

(b)

\begin{tabular}{lccr}
\hline & Free enzyme & $\begin{array}{c}\text { Residual activity (\%) } \\
\text { Entrapped enzyme }\end{array}$ & Cross-linked \\
\hline $\begin{array}{l}\text { Metal ions }(5 \mathrm{mM}) \\
\mathrm{NaCl}\end{array}$ & $124.9 \pm 5.66$ & $73.6 \pm 2.92$ & $74.2 \pm 3.21$ \\
$\mathrm{KCl}$ & $166.6 \pm 6.84$ & $92.1 \pm 4.25$ & $96.9 \pm 4.47$ \\
$\mathrm{MgCl}_{2}$ & $93.8 \pm 3.62$ & $57.5 \pm 2.43$ & $63.5 \pm 3.02$ \\
$\mathrm{CaCl}_{2}$ & $84.6 \pm 2.68$ & $87.6 \pm 3.73$ & $80.6 \pm 3.45$ \\
$\mathrm{CoCl}_{2}$ & $33.4 \pm 1.32$ & $41.1 \pm 1.64$ & $38.0 \pm 1.12$ \\
$\mathrm{HgCl}_{2}$ & $9.8 \pm 1.02$ & $37.04 \pm 2.46$ & $39.9 \pm 1.82$ \\
$\mathrm{CdCl}_{2}$ & $15.9 \pm 1.68$ & $36.8 \pm 2.37$ & $35.9 \pm 2.54$ \\
$\mathrm{NiCl}_{2}$ & $59.9 \pm 5.23$ & $47.4 \pm 4.02$ & $49.8 \pm 4.17$ \\
$\mathrm{Lead} \mathrm{acetate}_{\mathrm{Chemicals}}(1 \mathrm{mM})$ & $35.2 \pm 2.63$ & $73.2 \pm 3.61$ & $78.9 \pm 4.23$ \\
$\mathrm{PMSF}^{*}$ & & & $127.3 \pm 6.55$ \\
$\mathrm{PHMB}^{\#}$ & $97.3 \pm 5.62$ & $104.9 \pm 6.10$ & $47.6 \pm 3.19$ \\
$\mathrm{DTNB}^{\dagger}$ & $4.7 \pm 0.58$ & $34.7 \pm 2.81$ & $53.2 \pm 2.58$ \\
EDTA $^{\ddagger}$ & $5.0 \pm 0.95$ & $29.4 \pm 1.66$ & $84.5 \pm 5.29$ \\
\hline
\end{tabular}

* PMSF: phenylmethanesulfonyl fluoride.

\#PHMB: para-hydroxymercurybenzoate.

${ }^{\dagger}$ DTNB: 5,5'-dithiobis-(2-nitrobenzoic acid).

${ }^{\ddagger}$ EDTA: ethylenediaminetetraacetic acid.

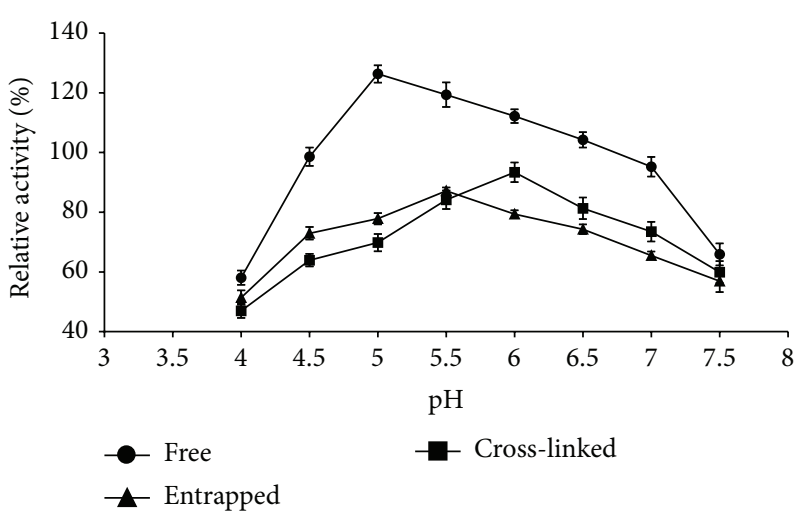

(a)

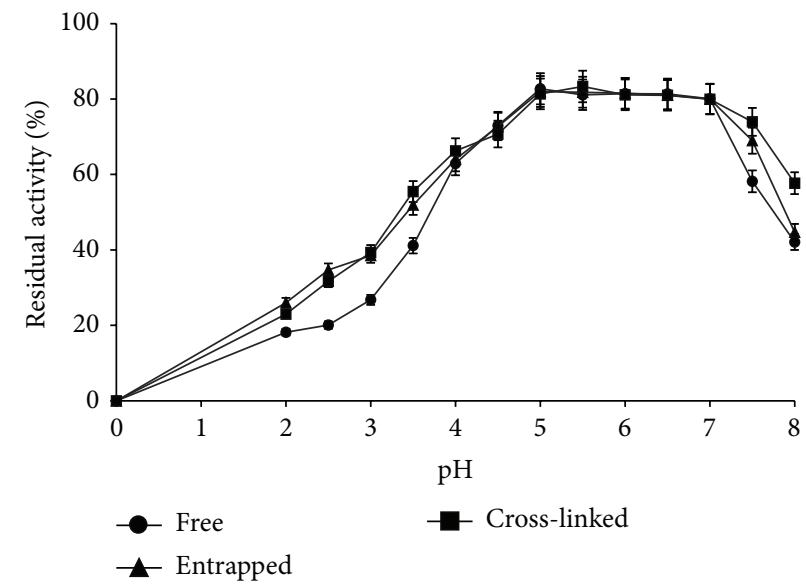

(b)

FIGURE 2: Comparison of $\mathrm{pH}$ optima (a) and pH stability (b) of free, entrapped, and cross-linked xylanase from A. flavus MTCC 9390. 


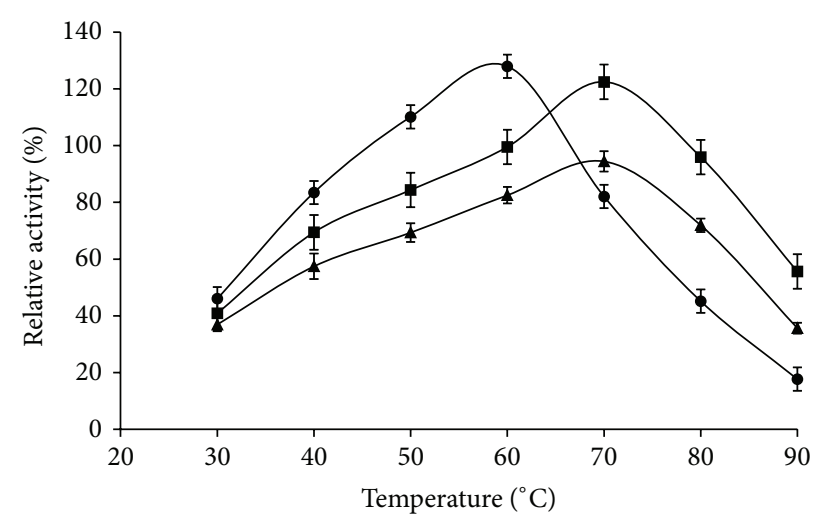

(a)

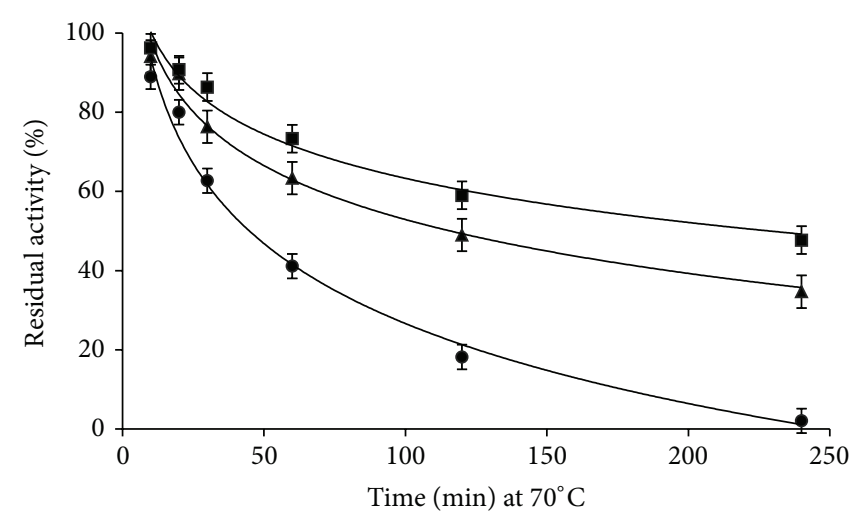

(b)

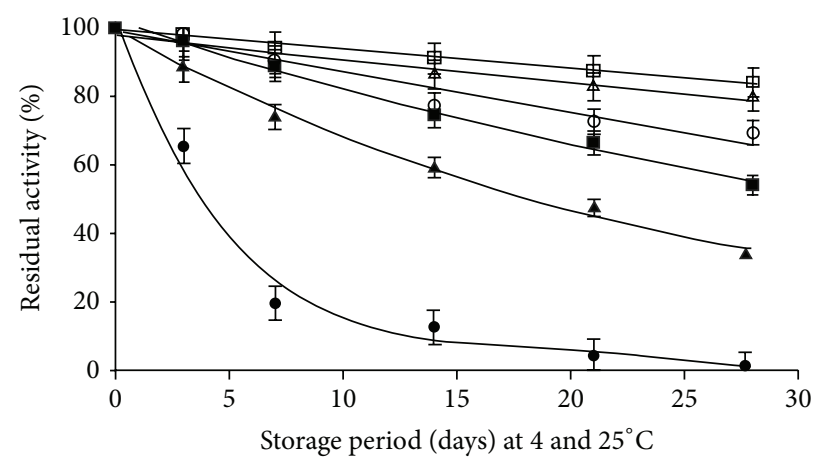

(c)

Figure 3: Comparison of temperature optima (a), thermostability (b), and storage stability at $4^{\circ} \mathrm{C}$ (open legend shapes $\mathrm{O}, \Delta$, and $\square$ ) and $25^{\circ} \mathrm{C}$

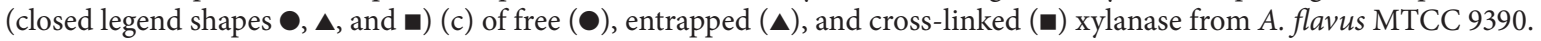

3.3. Stability Profile of Enzyme Preparations at Different Temperatures. Immobilization with cross-linking increased the thermostability of enzyme without any change in temperature optima as compared to the entrapped enzyme preparation (Figure 3(a)). Study showed that cross-linked enzyme retained $48 \%$ activity after $240 \mathrm{~min}$ at $70^{\circ} \mathrm{C}$ which was higher than the other two preparations (Figure 3(b)).

Storage stability studies showed that cross-linked enzyme preparation retained $54 \%$ activity as compared to $32 \%$ of entrapped preparation after $28 \mathrm{~d}$ storage at $25^{\circ} \mathrm{C}$ (Figure $3(\mathrm{c})$ ). This enhanced storage stability could be due to the better physical contacts or structural rigidness or stabilization of the enzyme. Similar results after cross-linking have been documented by Nwagu et al. [22]. The improved thermal stability at $60^{\circ} \mathrm{C}$ was obtained for lipase immobilized on chitosan-alginate beads activated with $2 \%$ glutaraldehyde. The immobilized enzyme was 33 times more thermostable than the soluble enzyme [12]. Thermostability studies of immobilized pectinase revealed that it retained $>80 \%$ of its initial activity after $5 \mathrm{~d}$ storage at $30^{\circ} \mathrm{C}$ while its free form retained only $30 \%$ of initial activity [24]. Coimmobilization in the alginate fibers and beads also resulted in protein leaching and decreased enzymatic activity after one month storage at $4^{\circ} \mathrm{C}$ [10]. Barbosa et al. [25] opined that thermal stabilizations of lipase- $\mathrm{B}$ at different $\mathrm{pH}$ values are consequences of both intramolecular chemical modification and intermolecular cross-linking which create the least damaging local environment.

Two independent variables, namely, $\mathrm{pH}$ and temperature optima, of xylanase catalyzed reaction were directionally displaced to different extent depending upon the nature of enzyme preparation (free or bound) and this shift is inherent feature of immobilization process $[2,5,23]$. In our previous study on thermoinactivation rate analysis of fungal xylanase, we found that thermal denaturation does not lead to unfolding but aggregation [26].

\subsection{Kinetic Constants and Velocity Saturations of Enzyme} Preparations. Immobilized enzymes are generally surrounded by a substrate concentration that is lower than the bulk concentration. Two different immobilization effectiveness factors, namely, stationary $(\eta)$ and operational $\left(\eta_{0}\right)$, were determined from substrate saturation curve and reaction progress curve, respectively (data not shown). Kinetic behavior of the free, entrapped, and cross-linked enzyme preparations showed a typical rectangular hyperbolic response with increasing concentration of substrate, a characteristic of Michaelis-Menten kinetics (Figure 4(a)). Free enzyme had $K_{m}$ and $V_{\max }$ of $1.53 \%$ and $200 \mathrm{UmL}^{-1}$, respectively, while a small decrease in $K_{m}(1.47 \%)$ and $V_{\max }\left(187 \mathrm{U} \mathrm{mL}^{-1}\right)$ of cross-linked enzyme preparation was observed (Figure 4(b)). It might be caused by either external 


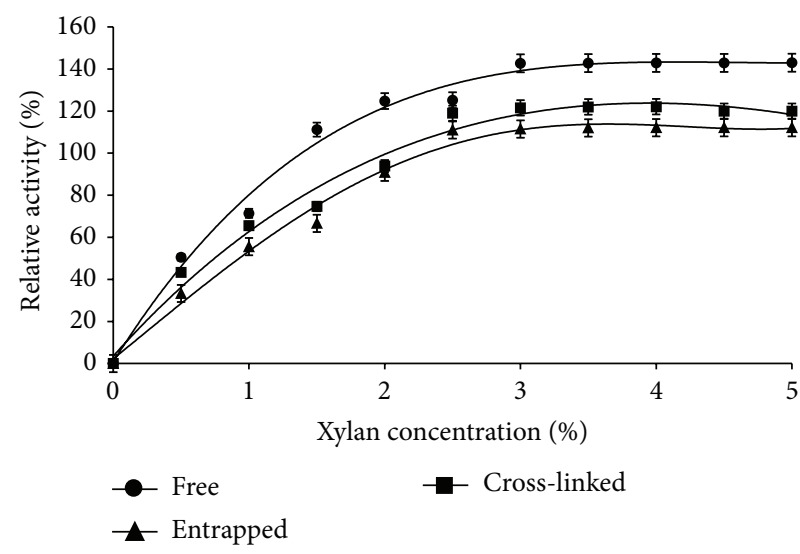

(a)

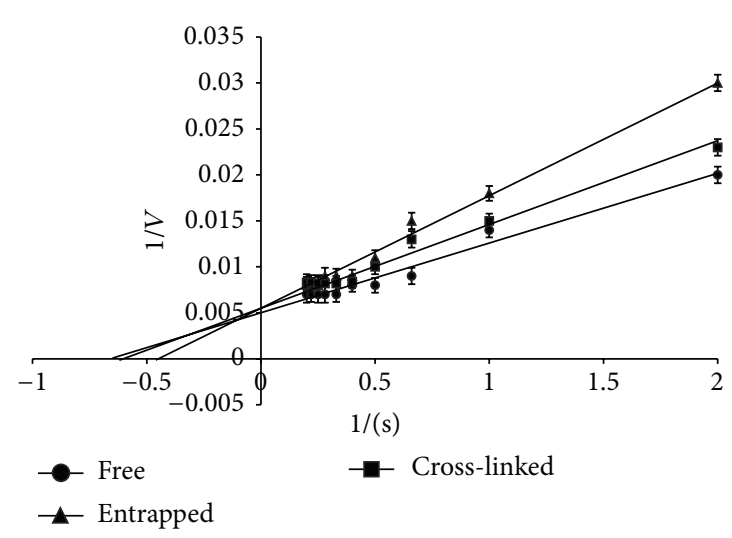

(b)

Figure 4: Comparison of saturation velocity curve (a) and double reciprocal plot (b) of free, entrapped, and cross-linked xylanase from $A$. flavus MTCC 9390.

$\left(\eta_{e}\right)$ or internal $\left(\eta_{i}\right)$ stationary effectiveness factors which correspond to diffusion layer and stearic hindrance inside the particles, respectively.

The apparent $K_{m}$ of lactase immobilized in carboxymethyl cellulose-alginate beads was $107.24 \mathrm{mM}$ as compared to $95.57 \mathrm{mM}$ for entrapped lactase in alginate. It might be due to increased surface area of beads and least diffusion resistance faced by substrate to accumulate inside the beads [27]. The apparent $K_{m}(2.08 \mathrm{mM})$ and apparent

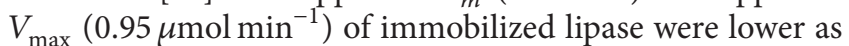
compared to free lipase $\left(K_{m} 8.0 \mathrm{mM} ; V_{\max } 2.85 \mu \mathrm{mol} \mathrm{min}{ }^{-1}\right)$ [19]. Similar work suggests that alginate network limits the permeation rates of substrate and product. Contrarily, polyacrylamide-entrapped peroxidase showed relatively lower $K_{m}$ value as compared to native peroxidase [28]. Complexion of amylase and glucosidase in alginate with pullulan not only decreased the $K_{m}$ but also increased the $V_{\max }[29]$.

3.5. Impact Assessment of Metal Ions and Chemicals. Studies on the effect of metal ions and modifiers suggested that immobilization by cross-linking method had a protective effect against harmful chemicals like mercury chloride and lead acetate commonly used in industrial processes (Table 1(b)). Interestingly, the free enzyme was activated by sodium chloride and potassium chloride whereas both the immobilized preparations were inhibited to varying extent. The reason behind this could not be ascertained in our study. The partial restoration of enzyme activity is in agreement with the previous report [30].

3.6. Reaction Progress. It was observed that, after entrapment and cross-linking, the reaction retention time for maximal activity was increased to $30 \mathrm{~min}$ from $15 \mathrm{~min}$ of free enzyme (Figure 5(a)). The observed increase in reaction time is due to diffusion of substrate molecules into calcium alginate beads which require greater time to reach the substrate binding site of immobilized enzyme.
As the reaction progresses, the substrate concentration outside the beads and stationary effectiveness factor get changed. So the operational effectiveness factor comes into action which is clear from increased reaction time in both the immobilized enzyme preparations in comparison with free enzyme. Increased reaction time indicates increased resistance to diffusion faced by high molecular weight substrate. Similar results have been presented with microbial pectinase where time increased from 5 to $10 \mathrm{~min}$ after immobilization $[24,31]$.

3.7. Reusability. The most important parameter of immobilized enzymes for industrial application is their repeated use. So the operational stability of xylanase entrapped in alginate gel was assessed by reusing the immobilized enzyme for twelve cycles (Figure 5(c)). It was observed that, up to four cycles, there was no appreciable loss in activity but afterwards the activity started to decrease. After eight cycles, $63 \%$ of the initial activity was retained by entrapped enzyme. This loss in activity was concomitant with the reduction in protein content in beads (data not given). The immobilized xylanase was found to have good operational utility as evident by substantial retention of activity after eight consecutive cycles. After twelve cycles, most of the enzyme leaked out and the difference in activity in two preparations was $\sim 10 \%$. The loss in activity upon reusing of immobilized preparation is a general observation. A lesser loss in activity in cross-linked enzyme preparation may be attributed to the cross-linking of enzyme molecules by glutaraldehyde.

Significant loss in activity of immobilized xylanases has been reported by many workers [2, 24, 32]. They have shown that xylanases from various sources immobilized on various support could be reused up to six to ten cycles. The operational stability of enzymes has been reported to increase by immobilization and suggested to be exploited on industrial scale. Alginate entrapped lipase was active after 10 cycles without any loss in activity [33]. However, 40 to $50 \%$ loss in activities of xylanase and lipase entrapped on $\kappa$-carrageenan and calcium alginate beads has also been observed [34, 35]. 


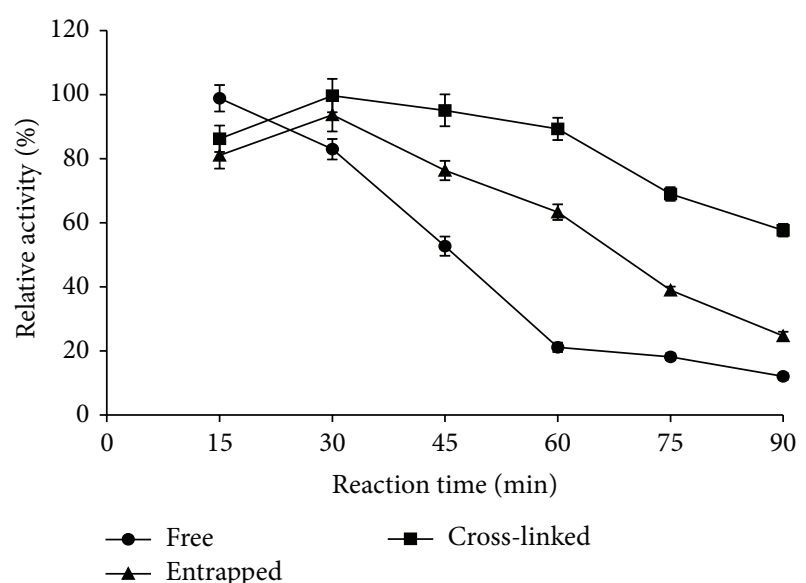

(a)

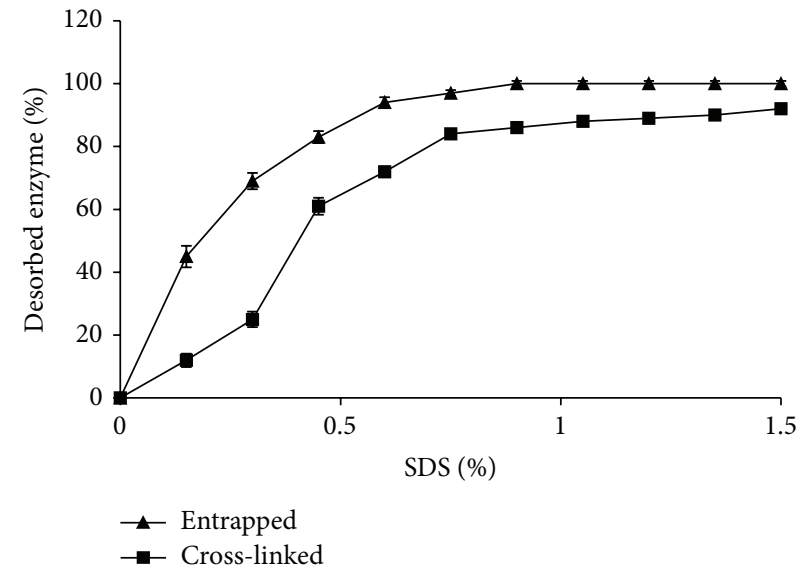

(b)

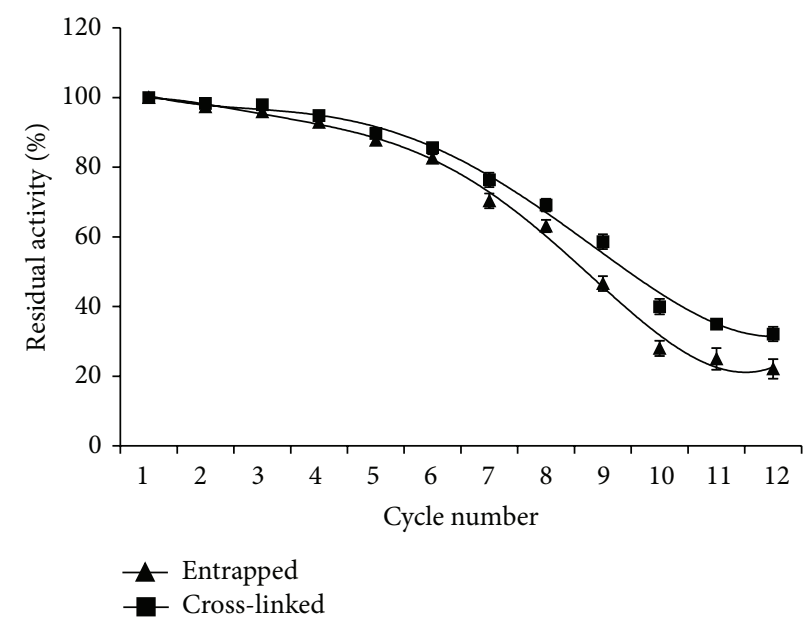

(c)

FIGURE 5: Reaction progress curve (a), desorptivity (b), and reuse of cross-linked and entrapped enzyme preparation (c) from A. flavus MTCC 9390.

No significant change in xylan hydrolysis by immobilized preparation up to ten cycles was observed by Roy et al. [20], while reusability of up to eight cycles has been reported by Silva et al. [12].

3.8. Desorptivity. It is important to note that, after a number of reuse cycles, enzyme gets deactivated and it should be removed from the matrix. The studies performed on desorption were also meant to take into consideration the marginal amount of enzyme likely to be loosely entrapped. It was found that $0.5 \%$ SDS was enough to desorb the enzyme from matrix even after cross-linking with glutaraldehyde (Figure 5(b)). This might be due to the competition of anionic surfactant with enzyme surface bound to the matrix.

Our results are in agreement with earlier reports which also provided similar suggestions $[25,36]$. Researchers have always paid attention to strongly cross-link the enzyme molecules in the polymer network with the help of linkers, aggregators, carriers, and composite materials [13, 27, 29, 37].

\section{Conclusion}

The application of xylanase in fruit juice industry includes clarification, liquefaction, and maceration of fruit pulp to increase juice yield. So the enzymes which have desirable characteristics such as the maximum reusable activity at high temperature and acidic $\mathrm{pH}$ have great potential since they can be introduced in different processing industries. Based on the observations, it could be suggested that A. flavus MTCC 9390 can be exploited at industrial scale for the production of xylanase. Immobilization with the cross-linking method improved the desirable characteristics such as thermostability and operational utility of the enzyme. So this method can be used to prepare xylanase-alginate beads for better xylanolytic activity and stability. Considering the method of enzyme employment and its effective reusability, this piece of work may contribute to pilot plant development of immobilized xylanase. But its commercial potential is still to evaluate since other studies like bioreactor output and food quality are equally essential. 


\section{Disclaimer}

The authors alone are responsible for the content and writing of the paper.

\section{Conflict of Interests}

The authors hereby declare that they have no conflict of interests.

\section{Acknowledgments}

The corresponding author is grateful to UGC-CSIR for the financial assistance in completing doctoral degree program and also to the Department of Chemistry \& Biochemistry, College of Basic Sciences \& Humanities, CCS Haryana Agricultural University, Hisar, 125004, India, for providing all the instrumentation and chemicals.

\section{References}

[1] I. G. Sandri, R. C. Fontana, D. M. Barfknecht, and M. M. da Silveira, "Clarification of fruit juices by fungal pectinases," LWT-Food Science and Technology, vol. 44, no. 10, pp. 22172222, 2011.

[2] B. Bhushan, A. Pal, S. Kumar, and V. Jain, "Biochemical characterization and kinetic comparison of encapsulated haze removing acidophilic xylanase with partially purified free xylanase isolated from Aspergillus flavus MTCC 9390," Journal of Food Science and Technology, vol. 52, no. 1, pp. 191-200, 2015.

[3] F. Gassara-Chatti, S. K. Brar, C. M. Ajila, M. Verma, R. D. Tyagi, and J. R. Valero, "Encapsulation of ligninolytic enzymes and its application in clarification of juice," Food Chemistry, vol. 137, no. 1-4, pp. 18-24, 2013.

[4] B. Bhushan, A. Pal, and S. Kumar, "Production and partial characterization of extracellular xylanase from acidophilic Aspergillus flavus MTCC 9390 grown in SSF mode," Research Journal of Biotechnology, vol. 9, no. 5, pp. 97-105, 2014.

[5] A. Pal and F. Khanum, "Covalent immobilization of xylanase on glutaraldehyde activated alginate beads using response surface methodology: characterization of immobilized enzyme," Process Biochemistry, vol. 46, no. 6, pp. 1315-1322, 2011.

[6] L. Cao, "Immobilised enzymes: science or art?" Current Opinion in Chemical Biology, vol. 9, no. 2, pp. 217-226, 2005.

[7] C. Mateo, J. M. Palomo, G. Fernandez-Lorente, J. M. Guisan, and R. Fernandez-Lafuente, "Improvement of enzyme activity, stability and selectivity via immobilization techniques," Enzyme and Microbial Technology, vol. 40, no. 6, pp. 1451-1463, 2007.

[8] K. Buchholz, V. Kasche, and U. T. Bornscheuer, "Characterization of immobilized catalysts," in Biocatalysts and Enzyme Technology, K. Buchholz, V. Kasche, and U. T. Bornscheuer, Eds., pp. 411-448, Boschstraße, Weinheim, Germany, 2012.

[9] H. Tumturk, G. Demirel, H. Altinok, S. Aksoy, and N. Hasirci, "Immobilization of glucose isomerase in surface-modified alginate gel beads," Journal of Food Biochemistry, vol. 32, no. 2, pp. 234-246, 2008.

[10] Z. Ölçer and A. Tanriseven, "Co-immobilization of dextransucrase and dextranase in alginate," Process Biochemistry, vol. 45, no. 10, pp. 1645-1651, 2010.
[11] N. A. M. Zain, M. S. Suhaimi, and A. Idris, "Development and modification of PVA-alginate as a suitable immobilization matrix," Process Biochemistry, vol. 46, no. 11, pp. 2122-2129, 2011.

[12] J. A. Silva, G. P. Macedo, D. S. Rodrigues, R. L. C. Giordano, and L. R. B. Gonçalves, "Immobilization of Candida antarctica lipase B by covalent attachment on chitosan-based hydrogels using different support activation strategies," Biochemical Engineering Journal, vol. 60, pp. 16-24, 2012.

[13] F. Jamal, T. Qidwai, D. Singh, and P. K. Pandey, "Biocatalytic activity of immobilized pointed gourd (Trichosanthes dioica) peroxidase-concanavalin A complex on calcium alginate pectin gel," Journal of Molecular Catalysis B: Enzymatic, vol. 74, no. 1-2, pp. 125-131, 2012.

[14] R. R. Yadav, S. N. Mudliar, A. Y. Shekh et al., "Immobilization of carbonic anhydrase in alginate and its influence on transformation of $\mathrm{CO}_{2}$ to calcite," Process Biochemistry, vol. 47, no. 4, pp. 585-590, 2012.

[15] B. Bhushan, A. Pal, and V. Jain, "Isolation, screening and optimized production of extracellular xylanase under submerged condition from Aspergillus flavus MTCC 9390," Enzyme Engineering, vol. 1, article 103, 2012.

[16] G. L. Miller, "Use of dinitrosalicylic acid reagent for determination of reducing sugar," Analytical Chemistry, vol. 31, no. 3, pp. 426-428, 1959.

[17] O. H. Lowry, N. J. Rosenbrough, A. L. Farr, and R. J. Randall, "Protein measurement with Folin-phenol reagent," The Journal of Biological Chemistry, vol. 193, no. 1, pp. 265-275, 1951.

[18] H. Lineweaver and D. Burk, "The determination of enzyme dissociation constants," Journal of the American Chemical Society, vol. 56, no. 3, pp. 658-666, 1934.

[19] J. J. Karimpil, J. S. Melo, and S. F. D’Souza, "Hen egg white as a feeder protein for lipase immobilization," Journal of Molecular Catalysis B: Enzymatic, vol. 71, no. 3-4, pp. 113-118, 2011.

[20] I. Roy, A. Gupta, S. K. Khare, V. S. Bisaria, and M. N. Gupta, "Immobilization of xylan-degrading enzymes from Melanocarpus albomyces IIS 68 on the smart polymer Eudragit L-100," Applied Microbiology and Biotechnology, vol. 61, no. 4, pp. 309313, 2003.

[21] R. Catana, B. S. Ferreira, J. M. S. Cabral, and P. Fernandes, "Immobilization of inulinase for sucrose hydrolysis," Food Chemistry, vol. 91, no. 3, pp. 517-520, 2005.

[22] T. N. Nwagu, H. Aoyagi, B. N. Okolo, and S. Yoshida, "Immobilization of a saccharifying raw starch hydrolyzing enzyme on functionalized and non-functionalized sepa beads," Journal of Molecular Catalysis B: Enzymatic, vol. 78, pp. 1-8, 2012.

[23] T. Li, N. Wang, S. Li, Q. Zhao, M. Guo, and C. Zhang, "Optimization of covalent immobilization of pectinase on sodium alginate support," Biotechnology Letters, vol. 29, no. 9, pp. 14131416, 2007.

[24] H. U. Rehman, A. Aman, A. Silipo, S. A. U. Qader, A. Molinaro, and A. Ansari, "Degradation of complex carbohydrate: immobilization of pectinase from Bacillus licheniformis KIBGE-IB21 using calcium alginate as a support," Food Chemistry, vol. 139, no. 1-4, pp. 1081-1086, 2013.

[25] O. Barbosa, R. Torres, C. Ortiz, and R. Fernandez-Lafuente, "The slow-down of the CALB immobilization rate permits to control the inter and intra molecular modification produced by glutaraldehyde," Process Biochemistry, vol. 47, no. 5, pp. 766-774, 2012.

[26] A. Pal and F. Khanum, "Purification of xylanase from Aspergillus niger DFR-5: individual and interactive effect of 
temperature and $\mathrm{pH}$ on its stability," Process Biochemistry, vol. 46, no. 4, pp. 879-887, 2011.

[27] T. H. A. Mai, V. N. Tran, and V. V. M. Le, "Biochemical studies on the immobilized lactase in the combined alginatecarboxymethyl cellulose gel," Biochemical Engineering Journal, vol. 74, pp. 81-87, 2013.

[28] S. A. Mohamed, A. S. Aly, T. M. Mohamed, and H. A. Salah, "Immobilization of horseradish peroxidase on nonwoven polyester fabric coated with chitosan," Applied Biochemistry and Biotechnology, vol. 144, no. 2, pp. 169-179, 2008.

[29] S. B. Jadhav and R. S. Singhal, "Pullulan-complexed $\alpha$-amylase and glucosidase in alginate beads: enhanced entrapment and stability," Carbohydrate Polymers, vol. 105, no. 1, pp. 49-56, 2014.

[30] I. Maalej-Achouri, M. Guerfali, A. Gargouri, and H. Belghith, "Production of xylo-oligosaccharides from agro-industrial residues using immobilized Talaromyces thermophilus xylanase," Journal of Molecular Catalysis B: Enzymatic, vol. 59, no. 1-3, pp. 145-152, 2009.

[31] H. U. Rehman, A. Aman, R. R. Zohra, and S. A. U. Qader, "Immobilization of pectin degrading enzyme from Bacillus licheniformis KIBGE IB-21 using agar-agar as a support," Carbohydrate Polymers, vol. 102, no. 1, pp. 622-626, 2014.

[32] M. Kapoor, R. K. Kapoor, and R. C. Kuhad, "Differential and synergistic effects of xylanase and laccase mediator system (LMS) in bleaching of soda and waste pulps," Journal of Applied Microbiology, vol. 103, no. 2, pp. 305-317, 2007.

[33] I. Bhushan, R. Parshad, G. N. Qazi, and V. K. Gupta, "Immobilization of lipase by entrapment in Ca-alginate beads," Journal of Bioactive and Compatible Polymers, vol. 23, no. 6, pp. 552-562, 2008.

[34] M. Sardar, I. Roy, and M. N. Gupta, "Simultaneous purification and immobilization of Aspergillus niger xylanase on the reversibly soluble polymer Eudragit ${ }^{\mathrm{TM}} \mathrm{L}-100$," Enzyme and Microbial Technology, vol. 27, no. 9, pp. 672-679, 2000.

[35] K. Won, S. Kim, K.-J. Kim, H. W. Park, and S.-J. Moon, "Optimization of lipase entrapment in Ca-alginate gel beads," Process Biochemistry, vol. 40, no. 6, pp. 2149-2154, 2005.

[36] J. Ran, S. Jia, Y. Liu, W. Zhang, S. Wu, and X. Pan, "A facile method for improving the covalent crosslinking adsorption process of catalase immobilization," Bioresource Technology, vol. 101, no. 16, pp. 6285-6290, 2010.

[37] H. Torabizadeh, M. Tavakoli, and M. Safari, "Immobilization of thermostable $\alpha$-amylase from Bacillus licheniformis by crosslinked enzyme aggregates method using calcium and sodium ions as additives," Journal of Molecular Catalysis B: Enzymatic, vol. 108, pp. 13-20, 2014. 

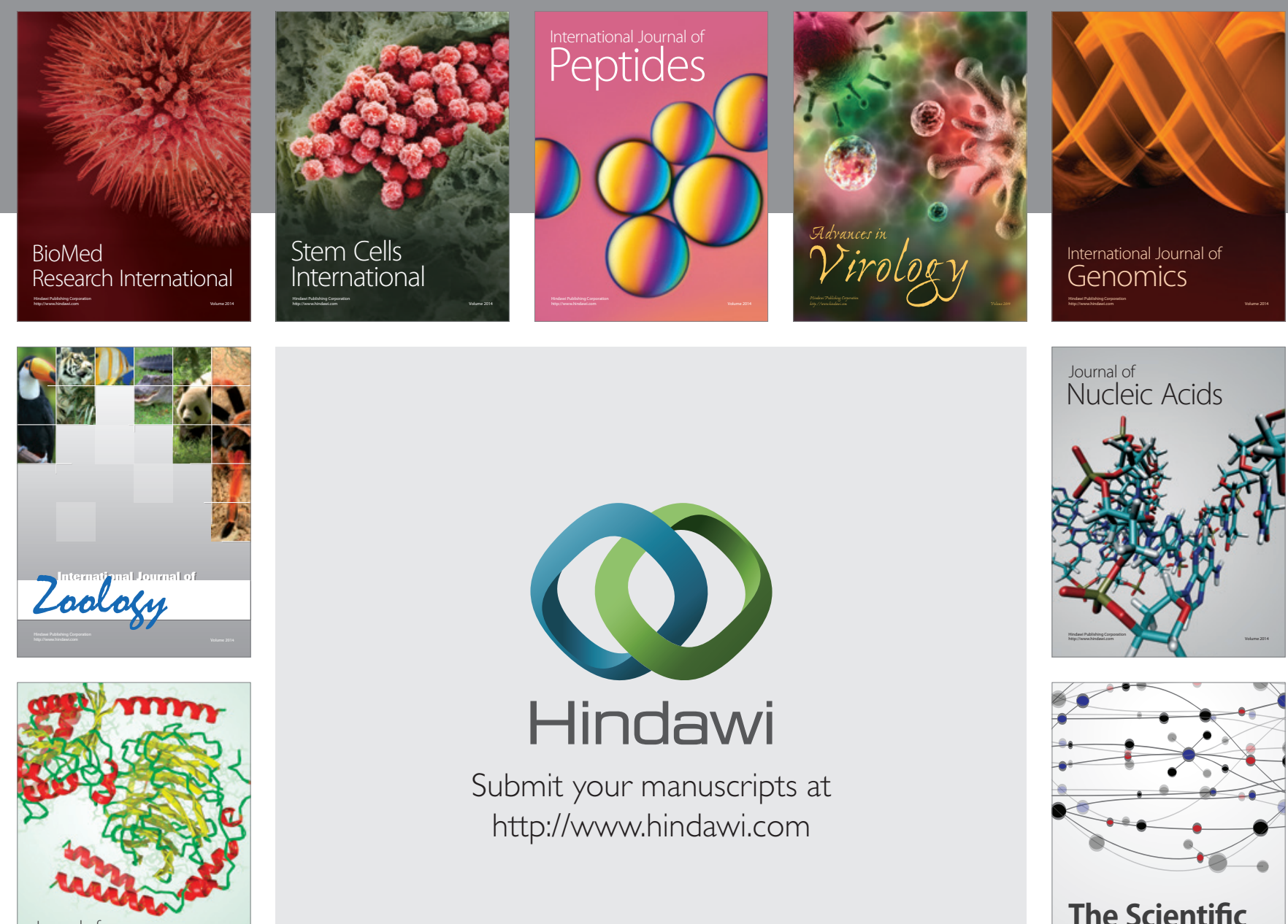

Submit your manuscripts at

http://www.hindawi.com

Journal of
Signal Transduction
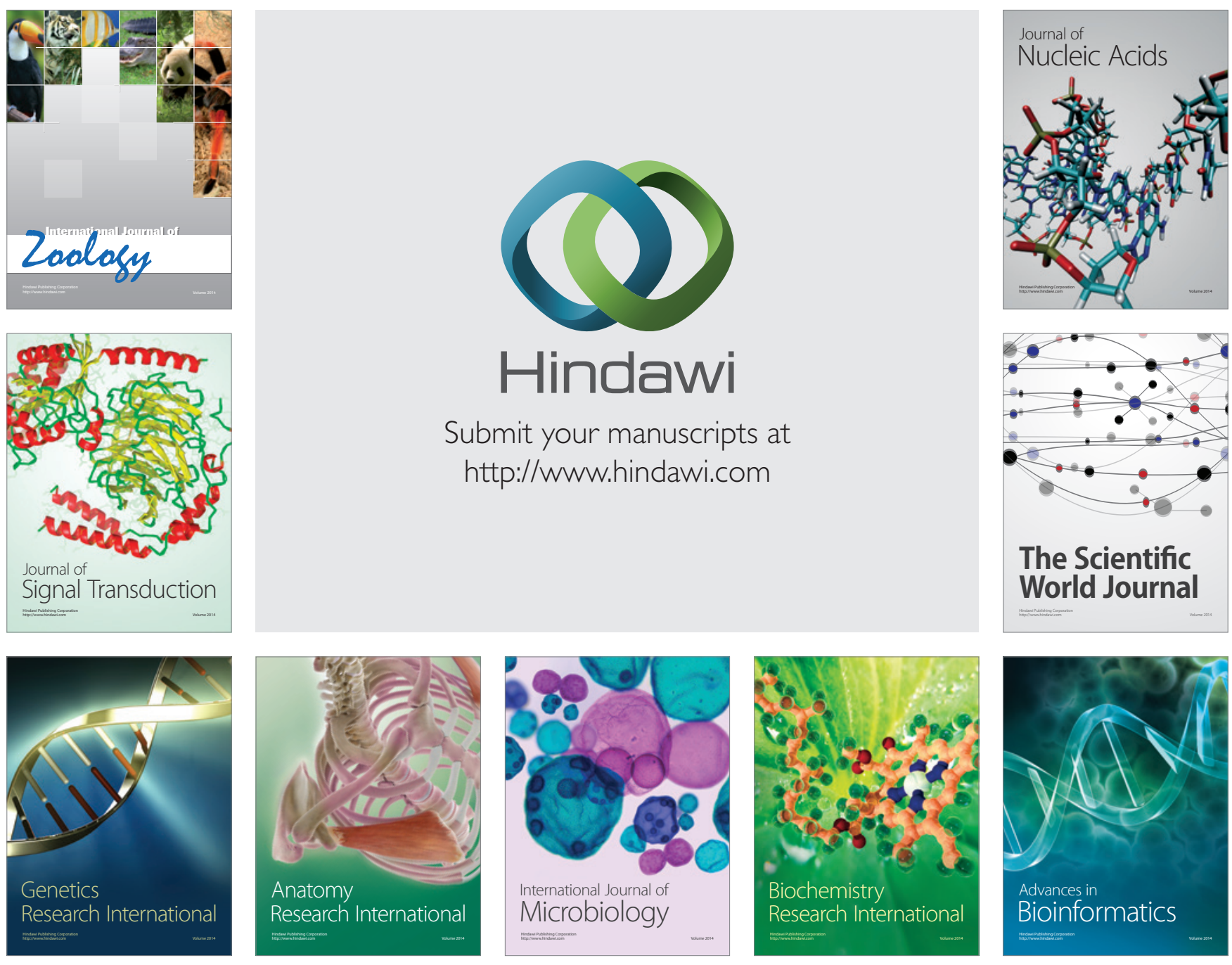

The Scientific World Journal
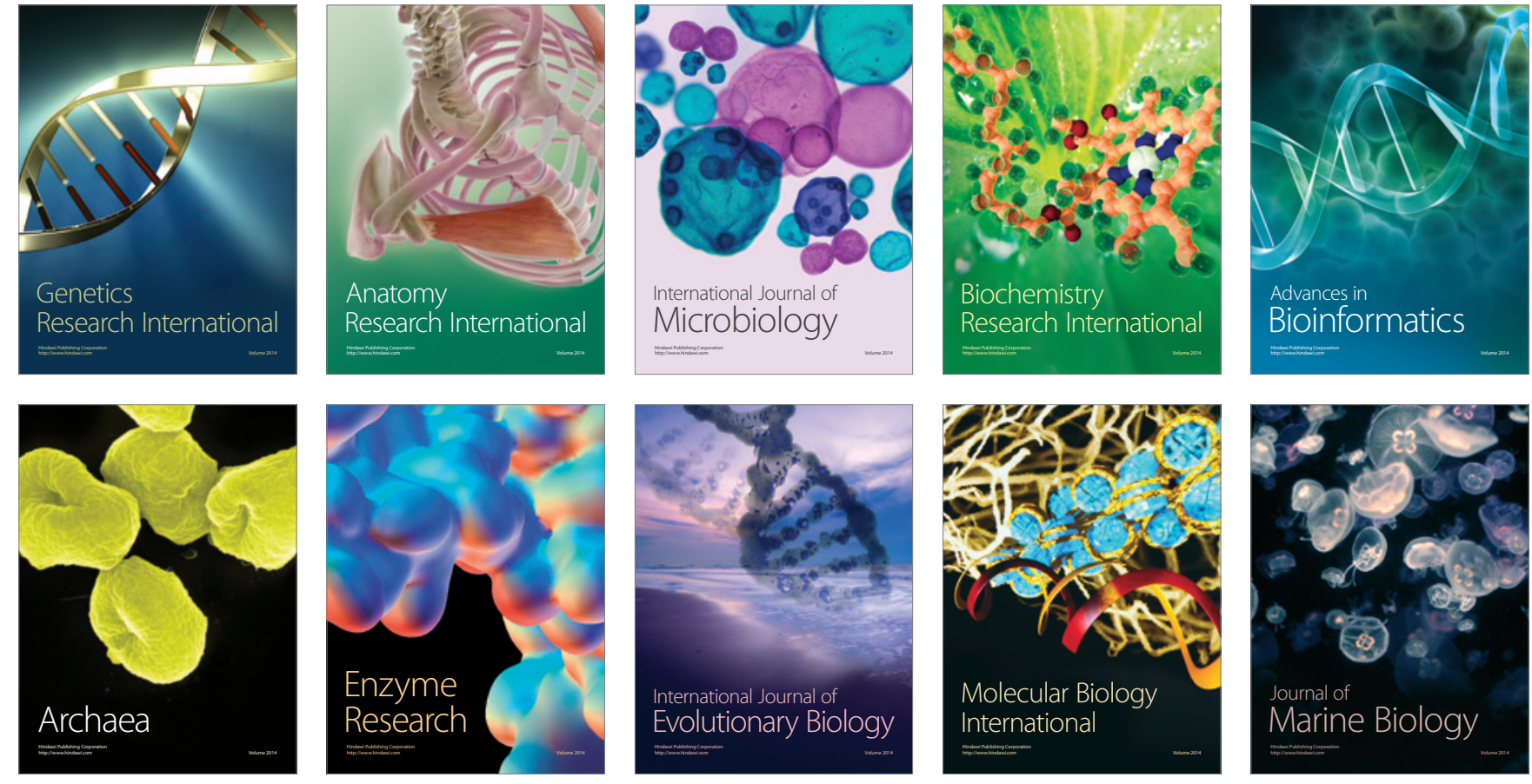